\title{
Robust laser positioning in a mobile robot machine vision system
}

\author{
Gurko A. G. ${ }^{1}$, Sergiyenko O. Yu. ${ }^{2}$, Lindner L. ${ }^{2}$ \\ ${ }^{1}$ Kharkiv National Automotive and Highway University, Ukraine \\ ${ }^{2}$ Universidad Autónoma de Baja California, Mexico
}

\begin{abstract}
Problem. Laser scanning devices are widely used in Machine Vision Systems (MVS) of an autonomous mobile robot for solving SLAM problems. One of the concerns with MVS operation is the ability to detect relatively small obstacles. This requires scanning a limited sector within the field of view or even focusing on a specific point of space. The accuracy of the laser beam positioning is hampered by various kinds of uncertainties both due to the model simplifying and using inaccurate values of its parameters, as well as lacking information about perturbations. Goal. This paper presents the improvement of the MVS, described in previous works of the authors, by robust control of the DC motor, which represents the Positioning Laser drive. Methodology. For this purpose, a DC motor model is built, taking into account the parametric uncertainty. A robust digital PD controller for laser positioning is designed, and a comparative evaluation of the robust properties of the obtained control system with a classical one is carried out. The PWM signal formation by the microcontroller and processes in the H-bridge are also taken into account. Results. The obtained digital controller meets the transient process and accuracy requirements and combines the simplicity of a classic controller with a weak sensitivity to the parametric uncertainties of the drive model. Originality. The originality of the paper is in its focus on the MVS of the autonomous mobile robot developed by the authors. Practical value. The implementation of the MVS with the proposed controller will increase the reliability of obstacles detection within a robot field of view and the accuracy of environment mapping.
\end{abstract}

Key words: DC motor, laser positioning, machine vision system, robust control.

\section{Introduction}

The performance of an autonomous mobile robot operating in an unknown cluttered environment requires to solve a number of tasks related to the mapping of the surroundings and determining the robot space-time orientation within the terrain (so-called SLAM) [1]. For these tasks solution, robots are equipped with Machine Vision Systems (MVS) based on different sensors (camera, laser, radar, sonar, lidar, etc.) [1] [16]. Laser scanners are attractive sensors in outdoor mobile robot localization and navigation [1], [3], [8]-[16] because of their ability to provide instantaneous information about the range and direction that can be used for feature extraction and obstacle detection. Fusing data from laser scanners with information from other sources benefits the accuracy of mapping and enables mobile robots to perform a variety of

tasks more confidently [1], [2], [12]. Though that coupling entails and disadvantages, e.g. it is necessary to decide which sensory system provides now the most proper information about the surrounding of the mobile robot [12].

One of the challenges, when used any type of the MVS, independent of the way of its implementation, is the ability to identify relatively small obstacles. That requires scanning of a limited sector of the field of view or even focusing on a specific point in space. In the case of a laser sensor, the solution of the mentioned problem is to increase the accuracy of the laser beam positioning at a given angle.

For this purpose, for example, in the proposed MVS in [12], the two stepper motors of the laser spot positioning (LP) system in the ver- 
tical and horizontal planes are replaced by DC motors [13]. Fig. 1. shows the latest prototype of a system with a DC Motor.

Using a DC motor instead of a stepper motor allows the laser beam to be rotated at any angle, so that the MVS can continuously scan a given limited sector within the field of view. Furthermore, a DC motor theoretically allows positioning the beam at any particular point.

However, the experiments [14], [15], [16] show that the new LP drive still has some drawbacks. These drawbacks are results of using inaccurate values of the parameters of the DC motor and the LP, simplification of the DC motor model, e.g. neglecting of some nonlinear effects, such as Coulomb friction; cogging torque for some of DC motors; friction coefficient jumpchanges in transitions; lacking information about perturbations and variations of the motor parameters values, etc. Thus, the implementation of the robust control of the LP drive is essential. Robust control of the LP drive will allow improving the accuracy and reliability of small obstacles detecting within the MVS field of view.

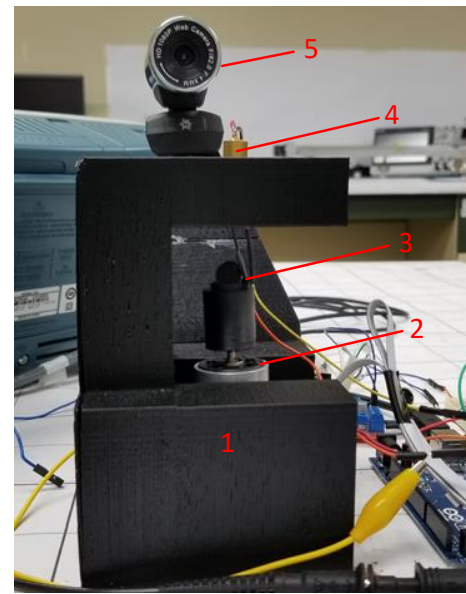

Fig. 1. Prototype of the Technical Vision System: 1 - Mounting base; 2 - Maxon REmax-29 DC Motor; 3 - 45-cut degree mirror Edmund Optics; 4 - Laser module Laserfuchs LFD650; 5 - USB Webcam 1080p AUSDOM

\section{Analysis of publications}

The popularity of DC motors as actuators for various technical objects have led to a large amount of research on robust control for these motors.

The first papers dedicated to robust control of DC motors appeared on early 1980s on the wave of interest to the rapidly developing theory of robustness. In particular, in [17], a microprocessor control system was developed in order to improve the drive performance of a DC servo motor and reduce sensitivity to parameter variations, nonlinear effects, and other disturbances. The control system consists of two independent loops: a position controller to specify the system transfer function and a complementary controller to reduce system sensitivity.

A robust system for a DC motor position control with a fuzzy controller and the additional compensator was presented in [18]. The additional compensator based on the sliding mode theory was used to improve the dynamical characteristics of the drive.

A sliding mode control coupled with a PID control was applied to control the motor speed in [19].

As the interest in the $\mathrm{H}^{\infty}$-control methods increased, they began to be used for the control of various plants including DC motors. Thus, in $[20,21] H^{\infty}$-controllers were designed for DC motors speed and position control using MATLAB Robust Control Toolbox. However, in spite of significant theoretical achievements, $H^{\infty}$ methods still do not spread in the everyday practice of actuators control. It is explained not only by the relative simplicity of implementation and comprehensibility of the 'traditional' PID controllers but also by the imperfection of $H^{\infty}$ algorithms, in particular, difficulties in determining the sensitivity function. Moreover, both the different varieties of enhanced PID controllers and the classical PID controllers can provide robust properties to the system [22, 23].

In [24] an analogue robust PD-controller for the laser actuator of the technical vision system has been proposed. However, this controller is not applicable for implementation by a microprocessor system since it does not take into account the specificities of numerical differentiation, signals digital filtering, and PWM control.

\section{Purpose and Tasks}

In this paper, we describe a robust digital PDcontroller with the coefficients that ensure the proper quality of the laser positioning under parametric uncertainty.

The paper is organized as follows. The dynamical model of the laser drive with uncertain parameters is described in the next section. Then the Simulink model of the system with the PDcontroller, tuned for the nominal drive model, is presented; it is followed by an analysis of the 
parametric uncertainties effect on the system performance. Afterwards, the robust PD-controller is designed, the robustness and performance of the system are also addressed in this section. Finally, concluding remarks are stated in the end of the paper.

\section{Laser drive mathematical model}

Since the DC motor is used as the drive for the LP system, in this section we will consider DC motor mathematical model. It is well known that the model of an armature-controlled DC motor is based on Newton's 2nd and Kirchhoff's voltage law and has the following form:

$$
\left\{\begin{array}{l}
L \frac{d i(t)}{d t}+R i(t)+K_{b} \frac{d \theta(t)}{d t}=V(t), \\
J \frac{d^{2} \theta(t)}{d t^{2}}+b \frac{d \theta(t)}{d t}=K_{m} i(t) .
\end{array}\right.
$$

where $L$ and $R$ are the electric inductance and electric resistance of a motor armature circuit respectively; $J$ is the total moment of inertia of the motor shaft together with the mirror; $i(t)$ is the armature current; $\theta(t)$ is the motor shaft position; $V(t)$ is the armature voltage; $K_{m}$ is the motor torque constant; $K_{b}$ is the back-EMF constant; $b$ is the motor viscous friction constant.

It is assumed in equation (1) that the magnetic field is constant and, therefore, the motor torque is only proportional to the armature current $i(t)$ by a constant factor $K_{m}$. In practice, the strength of the magnetic field can vary. Thus, that is one of the assumptions mentioned in the previous section, which simplifies the mathematical model but makes it less accurate. After simple transformations, taking $x_{1}=i(t), \quad x_{2}=d \theta(t) / d t, \quad$ and $x_{3}=\theta(t)$ as state coordinates, we get

$$
\begin{gathered}
{\left[\begin{array}{c}
\dot{x}_{1} \\
\dot{x}_{2} \\
\dot{x}_{3}
\end{array}\right]=\left[\begin{array}{ccc}
-\frac{R}{L} & -\frac{K_{b}}{L} & 0 \\
\frac{K_{m}}{J} & -\frac{b}{J} & 0 \\
0 & 1 & 0
\end{array}\right]\left[\begin{array}{l}
x_{1} \\
x_{2} \\
x_{3}
\end{array}\right]+\left[\begin{array}{c}
\frac{1}{L} \\
0 \\
0
\end{array}\right] u} \\
y=\left[\begin{array}{lll}
0 & 0 & 1
\end{array}\right]\left[\begin{array}{l}
x_{1} \\
x_{2} \\
x_{3}
\end{array}\right]
\end{gathered}
$$

where $y$ is the drive output coordinate and $u=V(t)$.
Fig. 2 shows a block diagram that corresponds to (2) and (3).

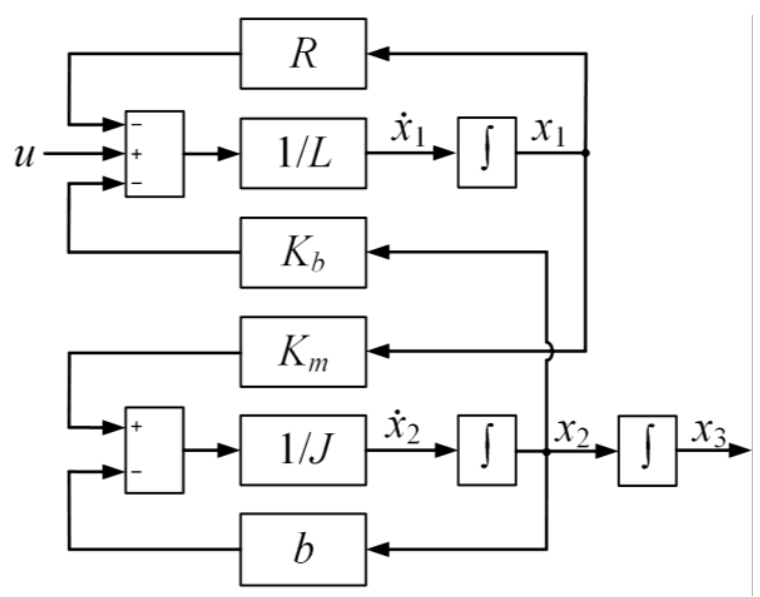

Fig. 2. The block diagram of the MVS laser drive

Assuming the constancy of the magnetic field is not the only simplification in the models (1) and (2), (3). In a realistic system, the exact values of the parameters $R, L, K_{\mathrm{b}}, K_{m}, J$ and $b$ are unknown. At the same time, we can always specify the bounded intervals to which these values belong [25]. That is, (2) can be rewritten as follows:

$$
\begin{gathered}
{\left[\begin{array}{c}
\dot{x}_{1} \\
\dot{x}_{2} \\
\dot{x}_{3}
\end{array}\right]=\left[\begin{array}{ccc}
-\frac{\bar{R}+\delta_{R}}{\bar{L}+\delta_{L}} & -\frac{\bar{K}_{b}+\delta_{K_{b}}}{\bar{L}+\delta_{L}} & 0 \\
\frac{\bar{K}_{m}+\delta_{K_{m}}}{\bar{J}+\delta_{J}} & -\frac{\bar{b}+\delta_{b}}{\bar{J}+\delta_{J}} & 0 \\
0 & 1 & 0
\end{array}\right]\left[\begin{array}{c}
x_{1} \\
x_{2} \\
x_{3}
\end{array}\right]+} \\
+\left[\begin{array}{c}
1 \\
\bar{L}+\delta_{L} \\
0 \\
0
\end{array}\right] u
\end{gathered}
$$

where $\overline{(\cdot)}$ represent the nominal values of the corresponding parameters and $\delta$ represent the possible perturbations on these parameters.

In this case, in the diagram of Fig. 2 the blocks with parameters $R, L, K_{b}, K_{m}, J$ and $b$ can be replaced with blocks $\bar{R}, \bar{L}, \bar{K}_{b}, \bar{K}_{m}, \bar{J}$ and $\bar{b}$ with feedbacks in terms of $\delta_{R}, \delta_{L}, \delta_{K b}, \delta_{K m}, \delta_{J}$ and $\delta_{b}$ (Fig. 3) [24]. 


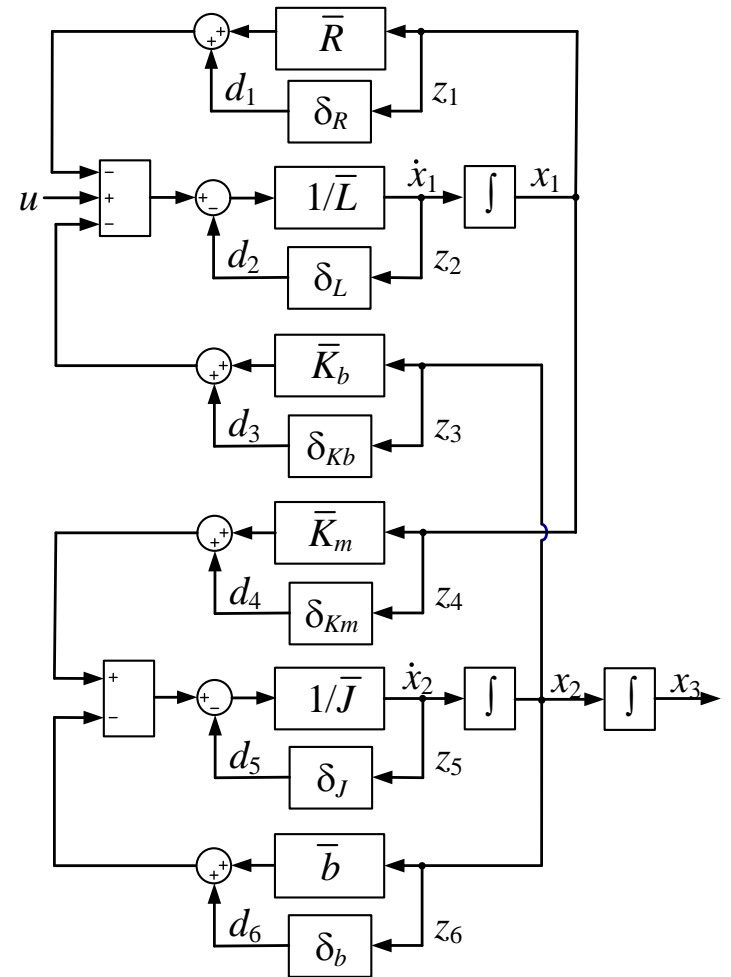

Fig. 3. The block diagram of the MVS laser drive with uncertain parameters

Using the model (Fig. 3) with undefined parameters allows us:

- to synthesize a controller for the LP system;

- to estimate the robustness of the obtained system and

- to evaluate the influence of the deviations $\delta_{R}, \delta_{L}, \delta_{K b}, \delta_{K m}, \delta_{J}$ and $\delta_{b}$ on the nominal parameters $\bar{R}, \bar{L}, \bar{K}_{b}, \bar{K}_{m}, \bar{J}, \bar{b}$ values at the system performance.

\section{Classic controller design}

This section presents the solution to the first listed above task. First, a PD-controller for the nominal model of the drive is designed. Then, we examine the robustness of the obtained system is. As a drive, we consider the DC motor Maxon RE-max29, which is used in the MVS (Fig. 1). The nominal values of the motor parameters taken from the manufacture datasheet [26] are listed in Table 1.

Table 1. DC motor Maxon RE-max29 parameters

\begin{tabular}{|l|l|l|l|}
\hline Symbol & $\begin{array}{c}\text { Nominal } \\
\text { value }\end{array}$ & \multicolumn{1}{|c|}{ Unit } & Variation \\
\hline$R$ & 104 & $\mathrm{Ohm}$ & $\pm 40 \%$ \\
\hline$L$ & 8.48 & $\mathrm{mH}$ & $\pm 40 \%$ \\
\hline$J$ & $7.2 \times 10^{-6}$ & $\mathrm{~kg} \cdot \mathrm{m}^{2}$ & $\pm 40 \%$ \\
\hline$K_{m}$ & 0.168 & $\mathrm{~N} \cdot \mathrm{m} / \mathrm{A}$ & $\pm 40 \%$ \\
\hline$K_{b}$ & 0.168 & $\mathrm{~V} \cdot \mathrm{s} / \mathrm{rad}$ & $\pm 40 \%$ \\
\hline
\end{tabular}

\begin{tabular}{|l|l|l|l|}
\hline$b$ & $2.71 \times 10^{-4}$ & $\mathrm{~N} \cdot \mathrm{m} \cdot \mathrm{s} / \mathrm{rad}$ & $\pm 40 \%$ \\
\hline
\end{tabular}

It is assumed, that the exact values of the motor parameters are unknown and they can range within $\pm 40 \%$ of their nominal values (Table 1 ).

The simulation was carried out using MATLAB/Simulink. First, a digital PDcontroller for the nominal motor parameter values (Table 1) was designed. Fig. 4 shows the Simulink model of the laser driver positioning system. The content of the 'DC Motor' block in Fig. 4 corresponds to the diagram in Fig. 2 without the last integrator converting the angular velocity $x_{2}$ to the angular position $x_{3}$.

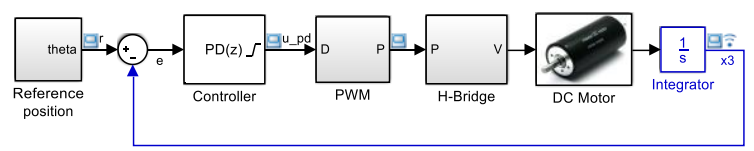

Fig. 4. The Simulink-model of the system with the driver nominal parameters

The motor is controlled by the PWM signal (Fig. 5). To amplify the signal and to reverse the direction of the motor shaft rotation the MOSFET H-bridge is used (Fig. 6). The PWM frequency is $488.28 \mathrm{~Hz}$. The maximum voltage fed to the laser driver is $12 \mathrm{~V}$. The PD algorithm is implemented using a microcontroller.

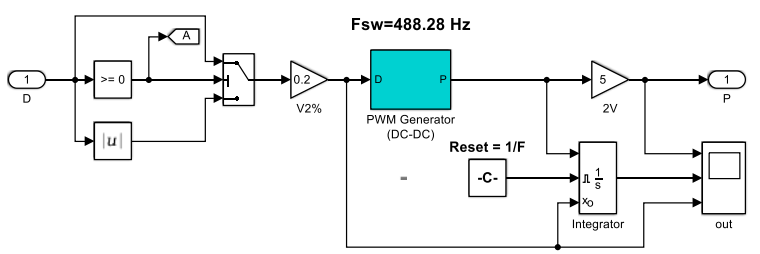

Fig. 5. The Simulink-model of the PWM subsystem in Fig. 4

The blocks 'Forward' and 'Backward' in Fig. $6 \mathrm{a}$ are to choose the direction of the motor shaft on the basis of the sign of the controller output; they are built with the help of switch blocks. The MOSFET Bridge model is exposed in Fig. 6b.

The system quality requirements are formulated based on the following considerations. According to [26], the nominal voltage of the Maxon RE-max 29 motor is $48 \mathrm{~V}$, and the nominal speed is $1820 \mathrm{rpm}$. This means that it makes one revolution in 0.033 seconds. Thus, at a supply voltage of $48 \mathrm{~V}$, the motor can turn at any angle up to $2 \pi$ in about $0.03 \mathrm{~s}$. In our laser MVS, the motor is fed with $12 \mathrm{~V}$, so it can be expected that it will turn 4 times slower. In fact, however, the effective sector of the robot MVS field of view is less than $\pi / 2$, therefore, $0.03 \mathrm{~s}$ is quite 
sufficient to turn the mirror to an arbitrary angle within the effective sector.

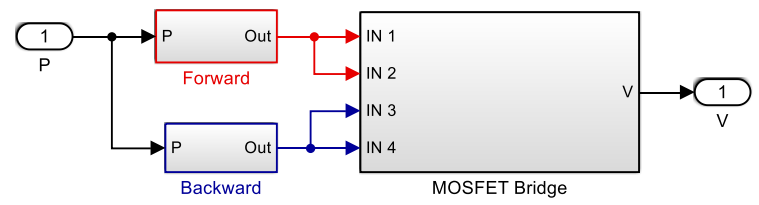

a

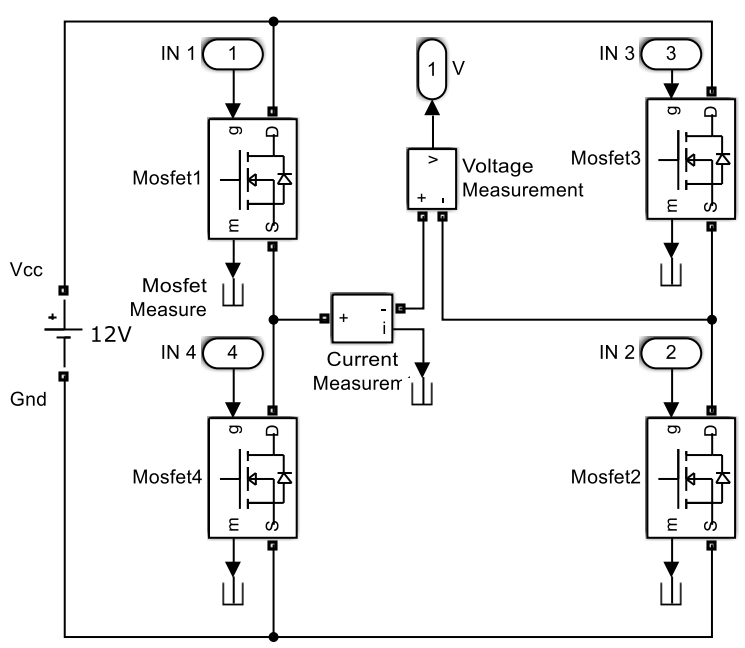

$\mathrm{b}$

Fig. 6. The Simulink-model of the H-bridge subsystem in Fig. 4: a - general form, bContent of the MOSFET Bridge subsystem

On the other hand, the transient process of the mirror positioning should have small overshot to ensure that the right position of the recently scanned spatial point will be finally fixed quickly enough. It minimizes the fuzziness of the light spot and, subsequently, allows measuring the 3D coordinates of this point as soon as possible. In other words, it permits to accelerate the scanning process, at least, without accuracy losses, and in the best case it permits to increase the 3D coordinate's accuracy due to the more precise positioning of the laser spot on the scanned surface.

Finally, the precision of the mirror positioning should be high enough to ensure the accuracy of the mapping of the environment and determining the shape of obstacles. Therefore, it is highly desirable that the steady-state error converges to zero. Thus, the design purpose is to meet the following requirements:

- the settling time should be less than $0.03 \mathrm{~s}$ with $2 \%$ tolerance;

- the overshoot of the system should tend to zero;

- no steady-state error.

Synthesis of a PD-controller for a determinis- tic object does not cause serious difficulties. For our case, first, a continuous model of the DC motor was used (Fig. 2), and the Ziegler-Nichols method was applied to find the preliminary values of the coefficients $k_{p}$ and $k_{d}$. Then, the controller was described with the transfer function (5), nonlinear elements were added to the control system (Fig. 4), the values of $T_{f}$ and $T_{s}$ in (5) were chosen and the coefficients $k_{p}$ and $k_{d}$ values were tuned manually.

$$
C(z)=k_{p}+\frac{k_{d} / T_{f}}{1+\frac{T_{s}}{T_{f}} \cdot \frac{z}{z-1}},
$$

where $k_{p}=20$ represents the controller proportional gain; $k_{d}=0.005$ the derivative gain, $T_{f}=0.01 \mathrm{~s}$ the filter time constant and $T_{s}=0.001 \mathrm{~s}$ the sampling time.

The simulation results are shown in Figs. 7 and 8. To test the performance of the LP system, the three command signals that correspond to $1.8,8.6$ and 14 degrees are applied to the system, and the responses are depicted in Fig. 7. These angles are chosen as far as they belong to sets of opening angles (scanning step angles) which are the most appropriate for the scanning with the laser MVS [27]. For example, the angles in the range 14.0-14.6 degrees are the biggest angles that permit to scan the scene the fastest possible way and without missing critical obstacles. The angle around 8.6 degree is the compromise between such constraints as "velocity" and "resolution". The step angle around 1.8-4.0 degrees provides the slowest scanning, and it is applicable for small obstacles detecting or for precise coordinate measurement on the edge of obstacle under highest interest for collision prevention in the path planning task of robot navigation.

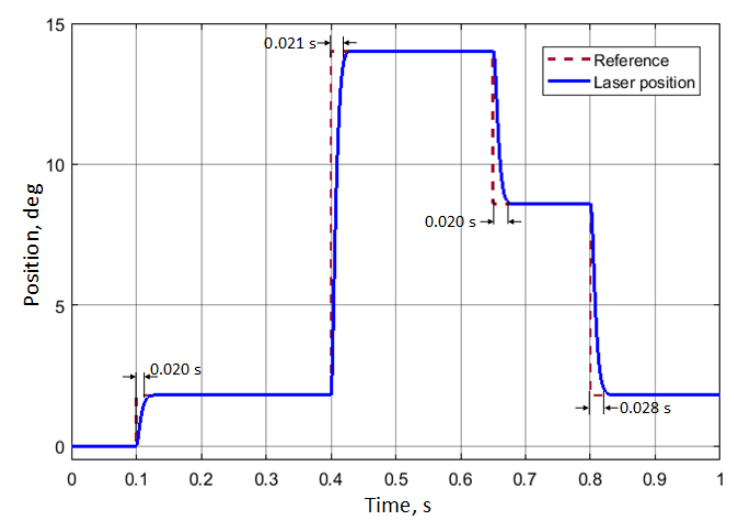

Fig. 7. The positioning of the laser drive 
From Fig. 7 it is seen that the system meets the mentioned requirements, for instance, the settling time is about $0.02 \mathrm{~s}$.

Fragment of the PWM signal fed to the laser drive which corresponds to the PD-controller output is presented in Fig. 8. This figure shows only the scaled part of the signals for clarity.

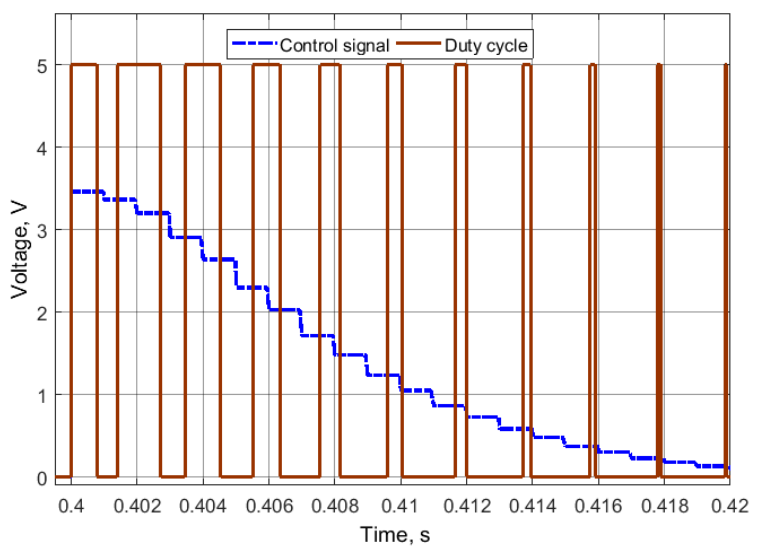

Fig. 8. The controller output and the corresponding PWM signal

\section{System Robustness Examination}

In spite of the fact that the obtained system meets the requirements, it is necessary to know how robust it is to variations of $R, L, K_{b}, K_{m}, J$ and $b$ within a certain range. Here we suppose that these parameters values can vary within the range of $\pm 40 \%$ of the nominal values (Table 1 ).

Step response plots for the system computed at random values of the uncertain parameters from the specified ranges and with the controller (5) are shown in Fig. 9.

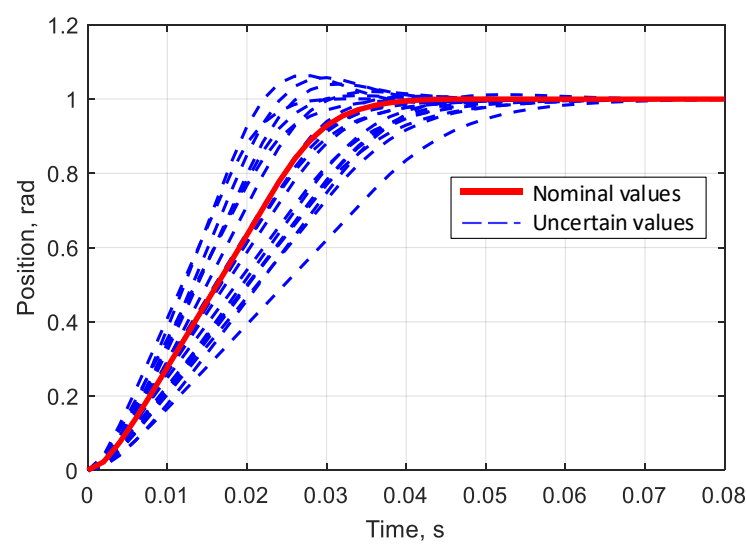

Fig. 9. The step responses for 20 values of the uncertain parameters for nominal tuning

From Fig. 7 and Fig. 9 it is obvious that though the controller (5), designed with the nominal model of the LP drive, meets the requirements for the transient process quality, the variations of the model parameters values have a significant impact on the system performance and, first of all, on the settling time (Fig. 9). Moreover, the overshoot can appear which is undesirable for our system.

To evaluate the impact of the deviation of each parameter value from the nominal ones on the linearized LP system performance, the values of $R$ and $L, b$ and $J, K_{m}$ and $K_{b}$ were varied in pairs; the other parameters values remained constant. As an impact index, we used the normalized value of the mentioned above tuning goals, generated by the MATLAB evalGoal function (Figs. 10-12). Normalized value of tuning requirement, returned as a positive scalar, which is a measure of how closely the requirements are met in the tuned system. To satisfy all the requirements the Performance in Figs. 10-12 should be less than 1 .

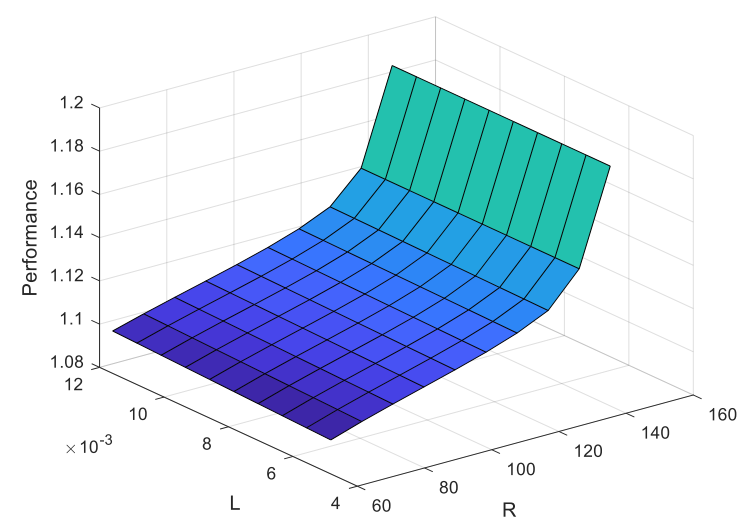

Fig. 10. The performance index over $R$ and $L$ versus nominal values of $J, b, K_{m}$ and $K_{b}$

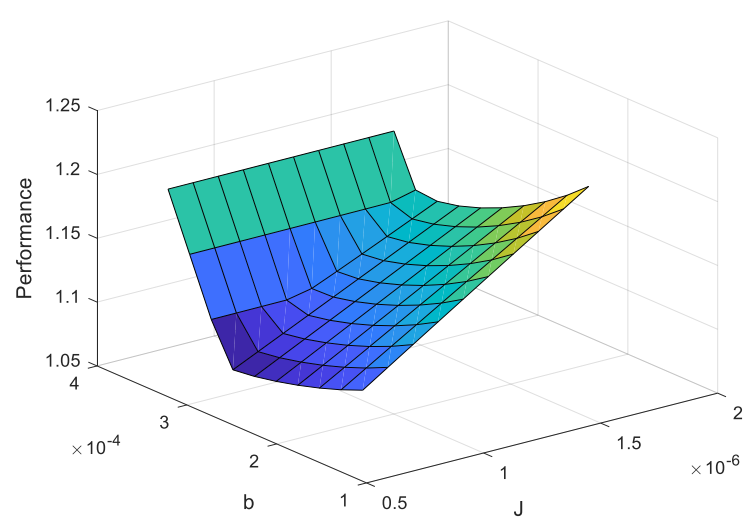

Fig. 11. The performance index over $b$ and $J$ versus nominal values of $R, L, K_{m}$ and $K_{b}$ 


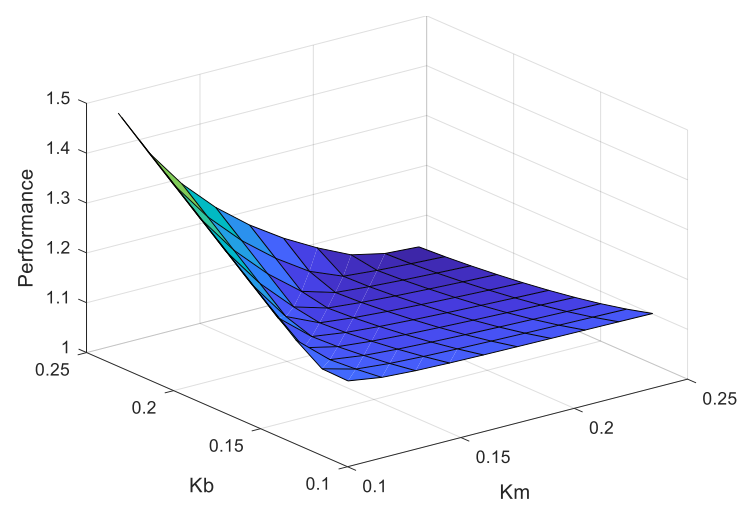

Fig. 12. The performance index over $K_{m}$ and $K_{b}$ versus nominal values of $b, J, R$ and $L$

These figures show that the nominal tuning is very sensitive to changes in the model values parameters. Though the values of $R, L, K_{m}$ and $K_{b}$ are given in the catalogue [26] (Table 1), and in practice, they are unlikely to change in such wide ranges as in Table 1, identifying the friction force value of the LP drive is a highly challenging task [14]. Thus, Figs. 10-12 indicate the necessity to use a robust controller to minimize the negative impact of uncertainties on the system dynamic.

\section{Robust controller}

To design a robust controller the MATLAB function systune() has been used, which yields the following controller parameters: $k_{p}=36.2$, $k_{d}=0.143$ and $T_{f}=2.31 \cdot 10^{-7}$. The robust properties of the system with the modified controller represent Fig. 13 and 14.

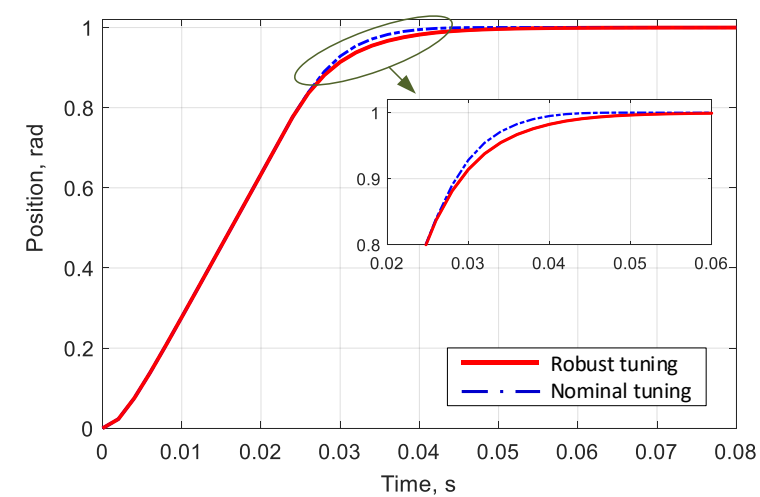

Fig. 13. The step responses for 20 uncertain parameters values for robust controller

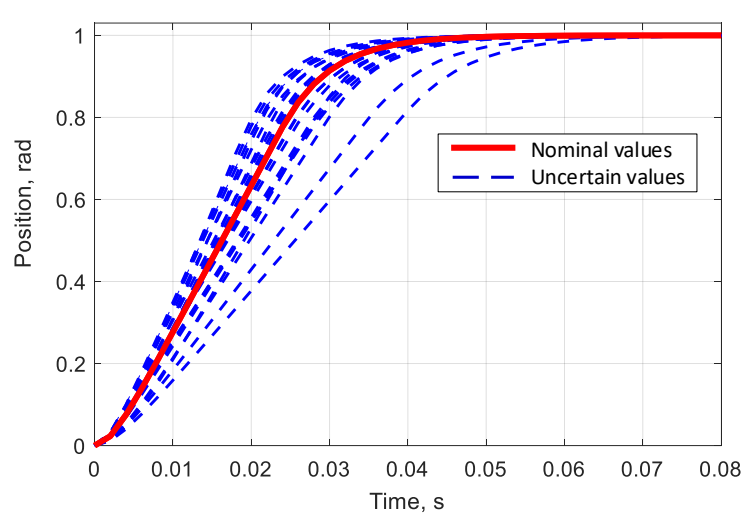

Fig. 14. The step responses for 20 uncertain parameters values for robust controller

The step response performance of the nominal LP system with the new controller is only slightly worse than the previous one (zoom on Fig. 13). Nevertheless, despite the similarity in the responses of the systems, the robust system does not have an overshoot at any combination of the uncertainties (Fig. 14), i.e. the robust controller provides better performance of the LP system over the nominal design. To ensure it the normalized parameter Performance is fond for all pairs of $R$ and $L, b$ and $J, K_{m}$ and $K_{b}$ (Figs. 15-17) by analogy with Figs. 10-12.

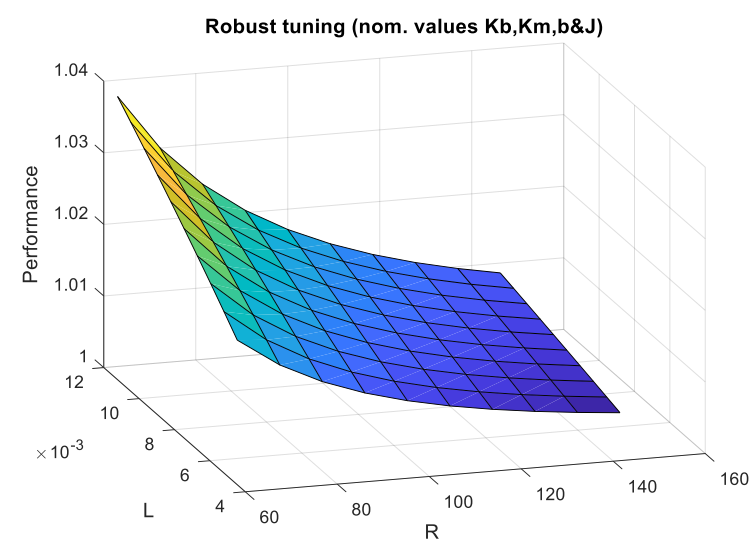

Fig. 15. The performance index for the robust system over $R$ and $L$ versus nominal values of $J, b, K_{m}$ and $K_{b}$

Figs. 15-17 show, that Performance indexes for the robust system are much closer to 1 than ones for the system with the controller, tuned for the nominal motor parameter values. 


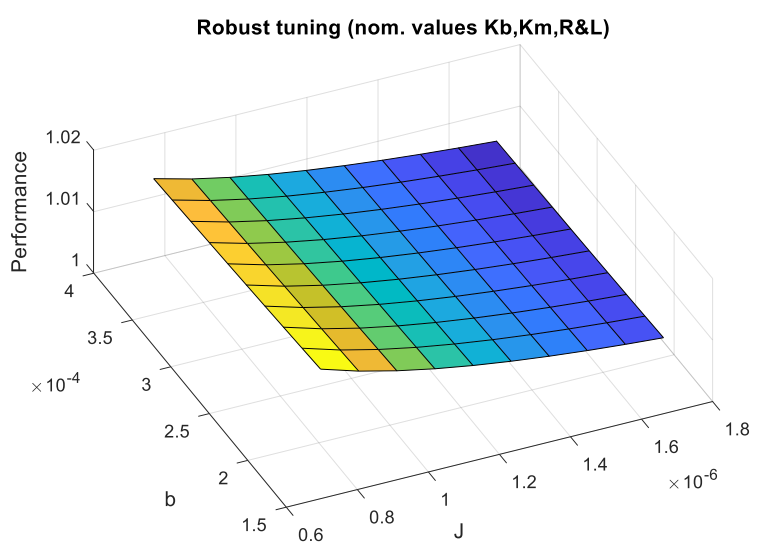

Fig. 16. The performance index for the robust system over $b$ and $J$ versus nominal values of $R, L, K_{m}$ and $K_{b}$

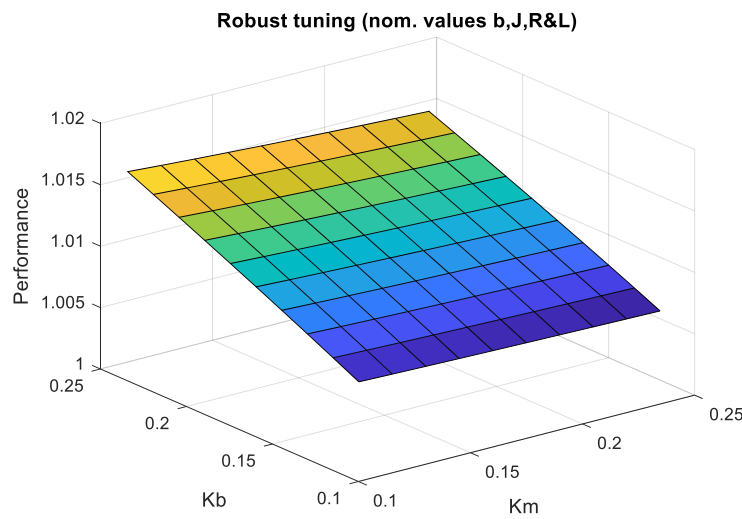

Fig. 17. The performance index for the robust system over $K_{m}$ and $K_{b}$ versus nominal values of $b, J, R$ and $L$

\section{Conclusion}

Efficiency improving of the laser MVS for mobile robotics is associated, among the other things, with the accuracy and velocity of the laser beam positioning.

The use of a DC motor as a laser drive instead of a stepper motor allows reducing the relative positioning error of the laser beam, nevertheless, there is the problem of reducing the of the modelling error effects on the laser positioning.

In this paper, to cope with the uncertainties of the laser positioning system, we presented a robust PD-controller. This controller combines the simplicity of the technical implementation of a classical controller with a weak sensitivity to the uncertainty's presence. The processes that occur during the formation of the PWM by a microcontroller, and in the H-bridge, are taken into account as well.

The effectiveness of the obtained laser positioning system drive is confirmed by simulation.

However, it is necessary to determine, how the system works under external uncertain dis- turbances. Investigation of this issue as well as the experimental study of the system is the task for future research.

\section{Conflict of interest}

The authors state that there is no conflict of interest regarding the publication of this paper.

\section{References}

1. Bresson G., Alsayed Z., Yu Li, and Glaser S., (2017). Simultaneous localization and mapping: a survey of current trends in autonomous driving. IEEE Transactions on Intelligent Vehicles, 20, 194-220. DOI: 10.1109/TIV.2017.2749181.

2. Li Z., Yang C., Su C.Y., Deng J., and Zhang W.. (2016). Vision-based model predictive control for steering of a nonholonomic mobile robot. IEEE Trans. on Control Systems Technology, 24(2), 553-564. DOI: 10.1109/TCST.2015.2454484.

3. N. Shalal, Low T., McCarthy C., and Hancock N.. (2015). Orchard mapping and mobile robot localisation using on-board camera and laser scanner data fusion - Part A: Tree detection. Computers and Electronics in Agriculture, 119, 254-266. DOI: 10.1016/j.compag.2015.09.025.

4. Su Z., et al. (2017). Global localization of a mobile robot using lidar and visual features. Proc. ROBIO, Macao, China, 2377-2383. DOI: 10.1109/ROBIO.2017.8324775.

5. Kumar G.A., et al. A LiDAR and IMU integrated indoor navigation system for UAVs and its application in real-time pipeline classification. (2017). Sensors, 17(6), 1268 [Online]. Available: http://dx.doi.org/10.3390/s17061268.

6. Kumar P., et al. An algorithm for automated estimation of road roughness from mobile laser scanning data. The Photogrammetric Record, 30(149), 30-45, 2015. DOI: 10.1111/phor.12090.

7. Song C., Wang X., and Cui N. (2018). MixedDegree Cubature Hळ Information Filter-Based Visual-Inertial Odometry. Applied Sciences, 9(1), 56. [Online]. Available: http://dx.doi.org/10.3390/app9010056

8. Huang K. and Stachniss C. (2018). Joint ego-motion estimation using a laser scanner and a monocular camera through relative orientation estimation and 1-DoF ICP. Proc. IROS, Madrid, Spain, 671-677. DOI: 10.1109/IROS.2018.8593965

9. Ivanov M., et al. (2019). Mobile Robot Path Planning Using Continuous Laser Scanning. Optoelectronics in Machine Vision-Based Theories and Applications, IGI Global, 338-372. [Online] Available: DOI: 10.4018/978-1-52255751-7.ch012.

10. Wen S., et al. (2018). Camera recognition and laser detection based on EKF-SLAM in the autonomous navigation of humanoid robot. Journal of Intelligent \& Robotic Systems, 92(2), 
256-277. DOI: https://doi.org/10.1007/s10846017-0712-5.

11. Zhao P., et al. (2018). Panoramic Image and Three-Axis Laser Scanner Integrated Approach for Indoor 3D Mapping. Remote Sensing, 10(8), $1269 . \quad$ [Online]. Available: http://dx.doi.org/10.3390/rs10081269

12. Basaca-Preciado L. C., et al. (2014). Optical 3D laser measurement system for navigation of autonomous mobile robot. Optics and Lasers in Engineering, 54, 159-169. DOI: 10.1016/j.optlaseng.2013.08.005.

13. Lindner L., et al. (2016). Mobile robot vision system using continuous laser scanning for industrial application. Industrial Robot, 43(4), 360-369. DOI: 10.1108/IR-01-2016-0048.

14. Lindner L., et al. (2017). Machine vision system errors for unmanned aerial vehicle navigation. Proc. ISIE, Edinburgh, UK, 1615-1620. DOI: 10.1109/ISIE.2017.8001488.

15. Reyes-García M., et al. (2018). Reduction of angular position error of a machine vision system using the digital controller LM629. Proc. IECON 2018, Washington, D.C., USA, 3200-3205.

16. Lindner L., et al. (2016). UAV remote laser scanner improvement by continuous scanning using DC motors. IECON 2016, Florence, Italy, 371-376. DOI: 10.1109/IECON.2016.7793316.

17. Tamaki K., et al. (1986). Microprocessor-based robust control of a DC servo motor. IEEE Control Systems Magazine, 6(5), 30-36, 1986. DOI: 10.1109/MCS.1986.1105133.

18. Fallahi M. and Azadi S. (2009). Robust control of DC motor using fuzzy sliding mode control with PID compensator. IMECS, Hong Kong, China, 2, 5. [Online]. Available: http://citeseerx.ist.psu.edu/viewdoc/download?doi $=10.1 .1 .148 .9267 \& \mathrm{rep}=\mathrm{rep} 1 \&$ type $=\mathrm{pdf}$

19. Eker I. (2006). Sliding mode control with PID sliding surface and experimental application to an electromechanical plant. ISA Trans., 45(1), 109118. DOI: 10.1016/S0019-0578(07)60070-6.

20. Březina L. and Březina T. (2011). H-infinity controller design for a DC motor model with uncertain parameters. Engineering Mechanics, 18, (5-6), 271-279.

21. Dey N., Mondal U., and Mondal D. (2016). Design of a H-infinity robust controller for a DC servo motor system. Proc. ICICPI, Kolkata, India, 27-31. DOI: 10.1109/ICICPI.2016.7859667.

22. Nguyen B. H., Ngo H. B., and Ryu J. H. (2009). Novel robust control algorithm of DC motors. Proc. URAI, Gwangju, Korea, 119-122.

23. Dorf R. C. and Bishop R. H. (2010). Modern Control Systems, 12th ed., Prentice Hall.

24. Гурко А.Г. (2019). Робастное управление приводом лазера системы технического зрения. Радиоэлектроника, информатика, управление, 1, 238-246. Gurko А. (2019). Robastnoe upravlenie privodom lazera sistemyi tehnicheskogo zreniya. [Robust control of laser actuator for technical vision system]. Radio Electronics Computer Science Control, 1, 238246. DOI: 10.15588/1607-3274-2019-1-22.

25. Gu D.-W., Petkov P. H., and Konstantinov M.M. (2013). Robust control design with MATLAB, 2nd ed., Springer Science \& Business Media.

26. Maxon RE-max Catalog. (2013). Maxon Motor, Sachseln, Switzerland. [Online]. Available: http://storkdrives.com/wp-content/uploads/2013/ 10/maxon-RE-max-catalog-data1.pdf

27. Garcia-Cruz X. M., et al. (2014). Optimization of 3D laser scanning speed by use of combined variable step. Optics and Lasers in Engineering, 54, 141-151. DOI: 10.1016/j.optlaseng.2013.08.011

Gurko Alaxander ${ }^{\mathbf{1}}$, Professor, Dr. of Sc, professor of the Automation and Computer-Integrated Technologies Department, +38(057) 738-77-92 gurko@khadi.kharkov.ua,

ORCID: 0000-0001-9905-8584.

Sergiyenko Oleg², Associate Professor, Dr. of Sc, srgnk@uabc.edu.mx. ORCID: 0000-0003-4270-6872. Lindner Lars ${ }^{2}$, PhD, lindner.lars@uabc.edu.mx. ORCID: 0000-0002-0623-6976.

${ }^{1}$ Kharkiv National Automobile and Highway University, 25, Yaroslava Mudrogo str., Kharkiv, 61002, Ukraine.

${ }^{2}$ Engineering Institute of Autonomous University of Baja California, Mexico, Blvd. Benito Juarez y Calle de la Normal, s/n, Col. Insurgentes Este, 21280, Mexicali, Baja California, Mexico.

Робастна система позиціонування лазера в системі машинного зору мобільного робота Анотація. Проблема. Рух автономного мобільного робота у невідомому оточуючому середовищі вимагає вирішення ряду завдань, пов'язаних із побудовою карти оточення та визначенням просторово-часової оріснтачіі робота на цій карті. Для вирімення вказаних завдань роботи обладнані системами машинного зору (СМЗ), до складу багатьох з яких входять лазерні сканери. Однією із проблем при використанні СМЗ є виявлення відносно невеликих перешкод. Для изього лазер повинен вміти з високою точністю сканувати обмежений сектор поля зору або фокусуватися на певній точиі простору. Однак, як СМЗ в цілому, так й привід лазера працюють в умовах невизначеності, що перешкоджає ефективному виконанню покладених на СМЗ завдань. Мета: підвищення надійності виявлення перешкоди в полі зору системи технічного зору робота за рахунок робастного керування приводом системи позииіонування лазера. Методологія. Побудована модель двигуна постійного струму, щзо $\epsilon$ 
приводом лазера у СМЗ, з урахуванням параметричної невизначеності. Синтезовано робастний ичирровий ПД-регулятор приводу позиціонування лазера. Проведена порівняльна оцінка робастних властивостей отриманої системи керування 3 системою 3 класичним регулятором. Ураховано процеси, щчо відбуваються при формуванні мікроконтролером ШІМ-сигналу, та у Н-мості. Результати. Одержаний цифровий регулятор задовольняє висунутим вимогам до якості перехідного процесу та точності у сталому режимі в умовах параметричної невизначеності. Орихінальність результатів роботи полягає у орієнтацію на розроблену авторами СТЗ автономного мобільного робота. Практичне значення. Застосування отриманого регулятора в лазерній СТЗ підвищить надійність виявлення перешкод $i$ точність побудови карти оточуючого робота середовища.

Ключові слова: двигун постійного струму, позииіонування лазера, система машинного зору, робастне керування.

Гурко Олександр Геннадійович ${ }^{1}$, д.т.н., проф. каф. автоматизації та комп'ютерно-інтегрованих технологій, gurko@khadi.kharkov.ua.

ORCID: 0000-0001-9905-8584.

Сергієнко Олег Юрійович ${ }^{2}$, д.т.н., доцент, srgnk@uabc.edu.mx. ORCID: 0000-0003-4270-6872.

Лінднер Ларс ${ }^{2}$, PhD, lindner.lars@uabc.edu.mx. ORCID: 0000-0002-0623-6976.

${ }^{1}$ Харківський національний автомобільнодорожній університет, 61002, Україна, м. Харків, вул. Ярослава Мудрого, 25.

${ }^{2}$ Інститут Інженерії Автономного університету Нижня Каліфорнія, м. Мехікалі, Нижня Каліфорнія, Мексика. 